\title{
Notes
}

\section{The Aftermath of Meritor: A Search For Standards in the Law of Sexual Harassment}

\author{
Marlisa Vinciguerra
}

[I]t may be too soon to know whether the law against sexual harassment will be taken away from us or turn into nothing or turn ugly in our hands.

Catharine A. MacKinnon, Feminism Unmodified (1987)

Sexual harassment law ${ }^{2}$ requires reassessment now, before women's protection from sexual harassment completely succumbs to a judiciallyinduced tranformation. Current sexual harassment law suffers from a doctrinal failure rooted in a chronic misapplication of causes of action. Two

1. C. MacKinnon, Feminism Unmodified: Discourses on Life and Law 105 (1987).

2. MacKinnon, author of the most influential book on sexual harassment, defines the term as "the unwanted imposition of sexual requirements in the context of unequal power." C. MAcKinNon, Sexual Harassment of Working Women 1 (1979). The Equal Employment Opportunity Guidelines on Sexual Harassment (EEOC Guidelines) describe sexual harassment as:

[U]nwelcome sexual advances, requests for sexual favors, and other verbal or physical activity of a sexual nature ... when (1) submission to such conduct is made either explicitly or implicitly a term or condition of an individual's employment, (2) submission to or rejection of such conduct by an individual is used as a basis of employment decisions affecting such individual, or (3) such conduct has the purpose or effect of unreasonably interfering with an individual's work performance or creating an intimidating, hostile or offensive working environment.

29 C.F.R. $\$ 1604.11$ (1988). Sexual harassment may take many forms, including homosexual harassment. See, e.g., Wright v. Methodist Youth Serv., 511 F. Supp. 307 (N.D. III. 1981). This Note, however, focuses upon sexual harassment of female subordinates by male supervisors in the workplace, because this form of harassment appears to be the most widespread. See N.Y. Times, Nov. 9, $1986, \S 3$ (Business), at 13 (7,273 complaints in 1985 by women subordinates). 
causes of action ${ }^{3}$ for sexual harassment under Title VII ${ }^{4}$ presently exist. Quid pro quo harassment occurs when "submission to sexual conduct is made a condition of concrete employment benefits"; it is properly conceptualized as sexual blackmail. The other cause of action for sexual harassment, the hostile environment claim, arises when hostility in the workplace negatively affects a victim's psychological health, and originated from an analogy to cases of abusive work environment because of race or national origin. ${ }^{6}$

The hostile environment claim has perplexed courts and precipitated a doctrinal failure in sexual harassment law: Gourts consistently define harassment involving certain forms of economic detriment as hostile environment harassment. ${ }^{7}$ Misuse of the hostile environment claim as a catch-all for sexual harassment complaints involving economic detriment limits quid pro quo analysis to the "clear-cut" or "paradigmatic" model, in which a supervisor verbally demands sexual submission, a woman refuses, and the supervisor immediately fires or demotes his recalcitrant victim. ${ }^{8}$

By relying upon the hostile environment framework to the exclusion of the quid pro quo cause of action in cases involving non-paradigmatic economic detriment, courts narrowly circumscribe the class of plaintiffs and types of behavior covered by quid pro quo harassment. This practice

3. Constructive discharge, loosely defined as involuntary resignation due to illegal and intolerable working conditions, is a corollary doctrine rather than a formal cause of action for sexual harassment. See infra note 15; Section $\mathrm{I}(\mathrm{C})$.

4. Civil Rights Act of 1964,42 U.S.C. $§ 2000$ e-2(a) (1982 \& Supp. IV 1986) (abolishing workplace discrimination based on sex).

5. Hicks v. Gates Rubber Co., 833 F.2d 1406, 1413 (10th Gir. 1988); see also Garber v. Saxon Business Prods., 552 F.2d 1032 (4th Cir. 1977); Williams v. Saxbe, 413 F. Supp. 654 (D.D.C. 1976) (first two cases finding sexual harassment violated Title VII). Until Williams, courts refused to recognize sexual harassment as sex discrimination. See Corne v. Bausch and Lomb, Inc., 390 F. Supp. 161 (D. Ariz. 1975), vacated without opinion, 562 F.2d 55 (9th Gir. 1977). For an explanation of the early development of sexual harassment doctrine, see Comment, Corne v. Bausch and Lomb, Inc.-Sexual Harassment and Title VII, 51 N.Y.U.L. REv. 148 (1976). Quid pro quo harassment presently is covered by Sections (1) and (2) of the Guidelines, supra note 2.

6. Hostile environment harassment exists when sexual conduct has "the purpose or effect of unreasonably interfering with an individual's work performance or creating an intimidating, hostile or offensive working environment." Meritor Sav. Bank v. Vinson, 477 U.S. 57, 65 (1986) (quoting EEOC Guidelines, 29 C.F.R. \$ 1604.11(a)(3)(1985)).

In Bundy v. Jackson, 641 F.2d 934, 943-44 (D.C. Cir. 1981), the first federal circuit court case to recognize hostile environment harassment, the court analogized the claim to the ethnic hostility claim initially recognized in Rogers v. EEOC, 454 F.2d 234 (5th Cir. 1971), cert. denied, 406 U.S. 957 (1972). In Rogers, the court found that doctors who segregated their Hispanic patients created a hostile work environment which discriminated against a Hispanic female employee. Id. at 239 (Goldberg, J., concurring separately). It is widely recognized that victims need not suffer economic detriment to prove this claim. E.g., Note, Sexual Harassment Claims of Abusive Work Environment Under Title VII, 97 HaRv. L. Rev. 1449, 1501 (1984) [hereinafter Note, Abusive Work Environment]. Courts agree. See, e.g., Huddleston v. Roger Dean Chevrolet, Inc., 845 F.2d 900, 905 (11th Cir. 1988) ("It is well settled that a plaintiff who alleges discrimination by sexual harassment does not have to demonstrate a 'tangible loss' of an 'economic character' in order to prove a violation of Title VII.")(citing Meritor, 477 U.S. at 63-66).

7. See infra note 10 and cases cited therein.

8. See, e.g., Horn v. Duke Homes, 755 F.2d 599, 603 (7th Cir. 1985) (example of clear-cut paradigm); infra Section $\mathrm{I}(\mathrm{A})$. 
reduces the availability of pecuniary relief, since quid pro quo but not hostile environment violations carry back-pay awards. ${ }^{9}$ It is essential to reclaim quid pro quo harassment as a remedy for all economic injuries caused by sexual harassment: Supervisors, with startling frequency, engage in sexual terrorism encompassing complex forms of economic retribution, which fall outside paradigmatic quid pro quo harassment. ${ }^{10}$

The case of Meritor Savings Bank v. Vinson, ${ }^{11}$ in which the Supreme

9. See 42 U.S.C. $\$ 2000$ e-5(g) (1982 \& Supp. 1985) (equitable remedies for Title VII plaintiffs). Quid pro quo plaintiffs are entitled to the equitable remedy of back-pay when they lose economic benefits as a result of discriminatory firing or lose the difference between present wages and wages which would have been earned in a failure to promote. See Bundy v. Jackson, 641 F.2d 943, 949-50 (D.C. Cir. 1981). Since hostile environment harassment theoretically (see infra note 10) exists independent of economic loss, relief for hostile environment violations remains limited to injunctions and reinstatement. See Bohen v. City of East Chicago, 799 F.2d 1180, 1184 (7th Cir. 1986). Courts have construed strictly the relief provisions of Title VII, and do not allow punitive damages nor monetary compensation for pain and suffering. See Note, Abusive Work Environment, supra note 6, at 1464. Attorney's fees have also been denied. Yates v. Avco Corp., 819 F.2d 630, 634 (6th Cir. 1987) (court denying attorney's fees for hostile environment violation); Bohen, 799 F.2d at 1183 (dicta discussing unavailabilty of attorney's fees under Title VII). But see Steele v. Offshore Shipbuilding, Inc. 867 F.2d 1311, 1318 (11th Cir. 1989) (allowing "reasonable" fees in hostile environment case). Furthermore, Congress, has failed to amend Title VII to authorize legal damages as relief. Note, Abusive Work Enviroment, supra note 6 at 1464 (proposing amending Title VII to include "comprehensive" damage relief).

10. Both before and after Meritor, the majority of sexual harassment plaintiffs in circuit court have pleaded facts giving rise to both causes of action. See Note, Abusive Work Environment, supra note 6 , at 1457 n.46 (early hostile environment plaintiffs who succeeded in stating a cause of action also plead quid pro quo harassment). The Note observes that although the plaintiffs in Bundy v. Jackson, 641 F.2d 934 (D.C. Cir. 1981) (failure to promote discussed infra Section II(A)(1)); Henson v. City of Dundee, 682 F.2d 897 (11th Cir. 1982) (constructive discharge and disciplinary action discussed infra section I(A)); and Katz v. Dole, 709 F.2d 251, 255 n.6 (4th Gir. 1983) (discriminatory failure to transfer), suffered economic detriment from sexual harassment, courts neglected to analyze their economic losses within the quid pro quo construct, and chose the hostile environment model to resolve the claims for relief. $I d$.

In other cases in which the facts implicate both causes of action, courts ignore or reject quid pro quo claims. For plaintiffs who were fired, failed to prove quid pro quo harassment and stated a claim for hostile environment harassment, see Meritor Sav. Bank v. Vinson, 470 U.S. 57, 64-65 (1986)(discussed infra Section II(A)(1) and note 11); Hicks v. Gates Rubber Co., 833 F.2d 1406, 1413-17 (10th Cir. 1987); Moylan v. Maries County, 792 F.2d 746, 749 (8th Cir. 1986) (discussed infra Section II(B)); Bohen v. City of East Chicago, Ind. 799 F.2d 1180, 1183 (7th Cir. 1986) (discussed infra Section II(A)(2)). Some plaintiffs prevailed on hostile environment grounds and failed to prove a constructive discharge. See Steele v. Offshore Shipbuilding, 867 F.2d 1311, 1317-18 (11th Cir. 1989); Huddleston v. Roger Dean Chevrolet, Inc., 845 F.2d 900, 905 (11th Cir. 1988); Yates v. Avco Corp., 819 F.2d 630, 637 (6th Cir. 1987); see also Section II(C). Other plaintiffs have proven constructive discharge due to hostile environment harassment. E.g. Jones v. Wesco Investments, 846 F.2d 1154, 1156 (8th Cir. 1988). A few plaintiffs lost on all grounds. Highlander v. K.F.C. Nat'l Management Co., 805 F.2d 644 (6th Cir. 1986); Jones v. Flagship Int'l, 793 F.2d 714, 716 (5th Cir. 1986). At least one woman has successfully established a prima facie case for both causes of action. Sparks $v$. Pilot Freight Carriers, 830 F.2d 1554 (11th Cir. 1987).

Co-worker hostile environment harassment, which is largely beyond the scope of this Note, may also involve economic detriment when plaintiffs allege constructive discharge. See Hall v. Gus Construction Co., 842 F.2d 1010, 1012 (8th Cir. 1988). For an analysis of co-worker harassment, see Note, Employer Liability For Co-worker Sexual Harassment Under Title VII, 13 N.Y.U. REv. L. \& Soc. Change 83 (1984-5).

11. 477 U.S. 57 (1986). For a review of the facts and procedural history of the case, see Vinson v. Taylor, 23 Fair Empl. Prac. Cas. (BNA) 37 (D.D.C. 1980); Vinson v. Taylor, 753 F.2d 143 (D.C. Cir. 1985). For an analysis and summary of the facts, see Holtzman \& Trelz, Recent Developments in the Law of Sexual Harassment: Abusive Environment Claims After Meritor, 31 ST. Louis U.L.J. 239, 249-256 (1987). The facts in Meritor were never resolved. The Supreme Court, 1985 
Court first reviewed a sexual harassment claim, ${ }^{12}$ provides the backdrop for examining the erosion of quid pro quo doctrine as well as the overextension of the hostile environment claim. The circuitous seven-year path of Mechelle Vinson's litigation, culminating with the Court's decision in Meritor, illustrates judicial resistance to accommodating non-paradigmatic economic harms within the rubric of quid pro quo harassment.

This Note attempts to unravel the confusion created by the judiciary's failure to recognize the often subtle interplay between hostile environment and quid pro quo harassment. Section I analyzes the framework courts apply to both types of sexual harassment claims and discusses the divergent liability standards applied to the two claims. ${ }^{13}$ Section II demonstrates how the judiciary's approach to sexual harassment, which excludes many claims of economic detriment from the quid pro quo model, undermines both hostile environment and quid pro quo doctrine. ${ }^{14}$ Constructive discharge ${ }^{15}$ presents one significant example of non-paradigmatic economic harm excluded from the quid pro determination and serves as an impetus for reform. Section III outlines the deleterious effects of current practices. Section IV proposes a methodology for deciding hostile environment claims accompanied by adverse economic effects. ${ }^{16}$ This Section also clarifies the differences between the two causes of action and demonstrates

Term-Leading Cases, 100 HaRv. L. Rev. 100, 278 (1986). Vinson alleged that her immediate supervisor Taylor threatened her continued employment and forced her to have sex with him. 23 Fair Empl. Prac. Cas. (BNA) at 38. She alleged he exposed his genitals to her, fondled her breasts and buttocks, watched her relieve herself in the bathroom and violently raped her-all of which occurred in the bank where they worked. Id. Further, she stated he fired her, after four years of this behavior. Id. Taylor denied all Vinson's allegations. Id. at 39. The Supreme Court and D. C. Circuit addressed only whether Vinson could maintain a hostile environment claim, although commentators have observed that Vinson's claim could have been characterized as quid pro quo harassment. See Note, Employer Liability for Sexual Harassment After Meritor Savings Bank v. Vinson, 87 Col.um. L. Rev. 1258, 1265 n.57 (1987)[hereinafter Note, Sexual Harassment After Meritor].

12. 477 U.S. 57 (1986).

13. The circuits currently apply vastly different liability tests. In Meritor, the Court "declined the parties' invitation to issue a definitive liability standard" but rejected strict liability or requiring the plaintiff to inform the employer of harassment. 477 U.S. at 69-72. The Court instructed lower courts to look to common law agency process for guidance. Id.

14. See infra Section III.

15. The original, awkwardly worded definition of constructive discharge with respect to Title VII is that "if the employer deliberately makes an employee's working conditions so intolerable that the employee is forced into an involuntary resignation, then the employer has encompassed a constructive discharge." Young v. Southwestern Savings and Loan Ass'n, 509 F.2d 140, 144 (5th Cir. 1975). Constructive discharge is an independent avenue of redress and is not defined as either cause of action for sexual harassment. See, e.g., Yates v. Avco Corp., 819 F.2d 631, 637-38 (6th Cir. 1987); Henson v. Dundee, 682 F.2d 897, 907-08 (11th Cir. 1982). To prove constructive discharge due to sexual harassment, plaintiffs must establish a Title VII violation based upon hostile environment or quid pro quo harassment and prove the violation caused resignation; in addition to mere proof of causation, some courts require proof of accompanying "aggravating factors" and/or that the employer intended the resignation. See infra Section $\mathrm{I}(\mathrm{C})$.

16. This approach differs from those which support a conflation of the two claims. See C. MAcKINNON, supra note 2, at 32; see also Note, Between The Boss and a Hard Place: A Consideration of Sexual Harassment After Meritor Savings Bank v. Vinson, 67 B.U.L. REv. 445 (1987) [hereinafter Note, Between the Boss]. An explanation of the differences between the single-claim approach and the approach advanced by this Note appears infra, at Section IV(A). 
that economic detriment always implicates quid pro quo harassment. This Note concludes that courts' failure to incorporate evolving forms of economic detriment into the quid pro quo model thwarts the remedial promise of Title VII.

\section{Sexual Harassment in the Courts}

A plaintiff must prove five separate elements to establish a prima facie case for any Title VII claim of sexual harassment: ${ }^{17}$ (1) that she belongs to a protected class; ${ }^{18}$ (2) that she was subject to unwelcome sexual harassment; ${ }^{19}$ (3) that this harassment was based on sex; ${ }^{20}$ (4) that the har-

17. The prima facie analysis for sexual harassment claims is borrowed from the disparate treatment model in Title VII jurisprudence. See McDonnell Douglas Corp. v. Green, 411 U.S. 792 (1971) (plaintiff must prove employer intent to discriminate). Use of the McDonnell-Douglas standards suggests that courts require a plaintiff to demonstrate intentional discrimination for both causes of action for sexual harassment. The Supreme Court, for example, stated in Meritor that intangible psychological injuries were "terms, conditions, or privileges of employment" under Title VII because Congress' use of that language "evinces a congressional intent to strike at the entire spectrum of disparate treatment of men and women." 477 U.S. at 64 (citing Los Angeles Dep't of Water \& Power v. Manhart, 435 U.S. 702, $707 \mathrm{n} .13$ (1977) (emphasis added)). In the Title VII context, if the prima facie case is made out, employer intent to discriminate is presumed. Comment, Help Wanted: An Expansive Definition of Constructive Discharge Under Title VII, 136 U. PA. L. REv. 941, 942 (1988) [hereinafter Help Wanted]. The other mode of analysis under the Title VII-disparate impact-does not require proof of discriminatory intent; rather victims must prove that facially neutral criteria had a discriminatory effect on a protected class. See Griggs v. Duke Power Co., 401 U.S. 424, 431 (1970). For an examination of the problems associated with intent-based requirements in antidiscrimination law, see Note, Advertising and Title VIII: The Discriminatory Use of Models in Real Estate Advertisements, 98 YALE L.J. 165, 171-74 (1988). With respect to sexual harassment law, two authors have noted that the "disparate treatment model is usually not well-suited to abusive environment claims." Holtzman \& Trelz, supra note 11, at 291. A recent Comment, however, has firmly accepted sexual harassment as disparate treatment discrimination by stating that "[t]he core of the typical harassment victim's claim is that she has been treated less favorably than her male counterparts-in other words, it is a disparate treatment claim." Comment, The Harms of Asking: Towards a Comprehensive Treatment of Sexual Harassment, 55 U. CHI. L. REv. 328, 330 (1988) [hereinafter Comment, The Harms of Asking]. Another commentator has described sexual harassment as neither disparate treatment nor disparate impact discrimination. See Note, Abusive Work Environment, supra note 6 , at 1511 . This Note concurs, and adopts the view that labelling particular forms of sexual harassment as "disparate treatment" may unduly restrict the availability of relief for harms which were not specifically intended by the employer. A discussion of the issue of burden shifting after a plaintiff makes out a prima facie case appears infra, at note 81 .

18. This element simply requires the parties to stipulate whether the plaintiff is a man or woman. Henson v. Dundee, 682 F.2d 897, 903 (11th Cir. 1982).

19. Unwelcomeness means that an employee did not solicit or incite the alleged behavior. Id. In Meritor, the Court distinguished "voluntariness" from unwelcomeness, and held that mere acquiescence to sexual harassment does not bar Title VII relief. 477 U.S. at 68 . The Court, however, would allow the evidence of a plaintiffs provocative speech or dress to determine unwelcomeness. Id. at 69 . See also Swentek v. USAIR, Inc. 830 F.2d 552, 557 (4th Cir. 1987) (discussing unwelcomeness). The unwelcomeness holding is particularly important because the trial court used Vinson's acquiescence to bar her quid pro quo claim, which was the only cause of action then recognized in the courts. See Vinson v. Taylor, 23 Fair Empl. Prac. Cas. (BNA) 37, 40 (D.D.C. 1980).

20. This element was initially difficult to prove. See Comment, The Harms of Asking, supra note 17, at 332. Now it is usually undisputed. Horn v. Duke, 755 F.2d 599, 604 (7th Cir. 1985). 
assment affected a term, condition, or privilege of employment; ${ }^{21}$ and (5) that her employer is liable. ${ }^{22}$

\section{A. The Quid Pro Quo Claim}

For quid pro quo harassment, courts construe the fourth element to read: "[T]he employee's submission to the unwelcome advances was an express or implied condition for receiving job benefits or that the employee's refusal to submit to a supervisor's sexual demands resulted in a tangible job detriment." ${ }^{23}$ Using tangible economic detriment as a distinguishing feature of quid pro quo harassment, courts define the second element, unwelcome sexual harassment, as sexual advances or threats which, when rejected by the employee, cause the supervisor to commit sexual extortion by depriving the victim of employment benefits. ${ }^{24}$ Courts focus upon the nexus between the alleged threats and economic detriment: The judicial gloss on the quid pro quo claim requires a clear temporal link between the advances or threats and adverse employment decisions. ${ }^{25}$

Accordingly, the quid pro quo claim rectifies the adverse economic effects of sexual harassment in the paradigmatic context-when women reject verbal advances or threats and their supervisors resort to prompt economic retaliation. ${ }^{26}$ For example, in Horn v. Duke Motor Homes, ${ }^{27}$ Horn's supervisor, Haas, made "remarks about her sexual needs now that her husband had left her" and told her that "he would make it easy on her if she would go out with him."28 Shortly after her final rejection of his

21. Courts require tangible detriment for quid pro quo harassment, Barnes v. Costle, 561 F.2d 983, 991 (D.C. Cir. 1977); see infra note 24, and psychological well-being for hostile environment, Jones v. Flagship Int'l., 793 F.2d 714, 719 (5th Cir. 1986); see infra note 32.

22. Under this element, employer liability is "a necessary proof under Title VII because that statute targets only the conduct of employers, labor organizations, and employment agencies." Comment, The Harms of Asking, supra note 17 at 344. See 42 U.S.C. $\S 2000(e)(b)(1986)$; infra Section II(C).

23. Highlander v. K.F.C. Nat'l Management Co., 805 F.2d 644, 648 (6th Cir. 1986); see also Downes v. FAA, 775 F.2d 288, 291-92 (Fed. Cir. 1985).

24. "Quid pro quo sexual harassment is anchored in an employer's sexually discriminatory behavior, which compels an employee to elect between acceding to sexual demands and forfeiting job benefits, continued employment or promotion, or otherwise suffering tangible job detriments." High lander, 805 F.2d at 648. See EEOC Guidelines, supra note 2, 29 C.F.R. $\$ \$ 1604.11$ (a)(1), (2).

25. See Horn v. Duke, 755 F.2d 599, 603 (7th Gir. 1985) (clear and close temporal nexus between plaintiff's rejection of her supervisor's sexual demands and discharge). In Meritor, the Court contrasted hostile environment harassment to quid pro quo harassment by stating that a hostile environment violation may be proven whether or not the harassment is "directly linked to the grant or denial of an economic quid pro quo." Meritor, 477 U.S. at 65.

26. Plaintiffs who allege economic retaliation temporally linked to the rejection of a supervisor's advances prevail on quid pro quo grounds. Sparks v. Pilot Freight Carriers, 830 F.2d 1154, 1556-57 (11th Cir. 1987). For example, in Sparks, a supervisor made sexual advances which the plaintiff rebuffed. Examples of this harassment included using the company loudspeaker to warn Sparks that "revenge is the name of the game" and "your fate is in my hands"; both the supervisor and Sparks were transfered to a new location; after three days at the new location, and two weeks after her last rejection of his sexual advances, the supervisor elicited the assistance of higher management to fire Sparks when she called in sick. Id.

27. 755 F.2d 599 (7th Cir. 1985).

28. Id. at 601-02. 
advances, Haas reprimanded Horn for "substandard work" and transferred her to another part of the production line. ${ }^{29}$ One week later, he fired her. ${ }^{30}$ The Seventh Circuit found a Title VII violation for quid pro quo harassment based largely upon Horn's showing that her firing occurred shortly after her last rejection of Haas' advances and resulted directly from her unwillingness to accede to these propositions. ${ }^{31}$

\section{B. The Hostile Environment Claim}

For claims of hostile environment harassment, courts interpret the fourth element of the prima facie case as requiring proof of psychological harm suffered by the employee, which Meritor recognized as a condition of employment. ${ }^{32}$ Since hostile environment harassment may exist independently of economic detriment, the unwelcomeness element also covers sexually abusive behavior not necessarily related to the denial of economic benefits, such as referring to women as female sexual organs or displaying pornography in the workplace. ${ }^{33}$ Plaintiffs proving hostile environment harassment are confined to injunctive relief and reinstatement because the hostile environment claim specifically seeks to redress non-economic injuries. $^{34}$

The nature and severity of hostility required to prove an alteration of a woman's psychological well-being eludes judicial definition. ${ }^{38}$ In Meritor, the Supreme Court approved the hostile environment claim as a viable cause of action, ${ }^{36}$ but applied the claim in the context of a plaintiff who suffered not only persistent non-economic harm, but also lost her job after

29. Prior to this incident, Horn had never been reprimanded by her supervisors. Id. at 602 .

30. Id.

31. The court found Horn's testimony more credible than that of Haas. Because the firing occurred soon after Horn's rejection of Haas' sexual demands and Horn competently performed her duties, Haas could not rebut the allegation of sexual harassment. Id. at 603 . For a description of burdens of proof for quid pro quo harassment claims under Title VII see infra note 81.

32. See generally EEOC Guidelines, 29 C.F.R. $\$ \S 1604.11$ (a) (1), (3) 1988. To be actionable, the offensive behavior must be severe enough to alter the conditions of employment. Meritor, 477 U.S. at 67 . "This test may be satisfied by showing that the sexual harassment was sufficiently severe and pervasive to affect seriously [the victim's] psychological well-being." Sparks v. Pilot Freight Carriers, 830 F.2d 1554, 1561 (11th Cir. 1987) (quoting Henson v. Dundee, 682 F.2d 897, 904 (11th Cir. 1982)). Not all workplace conduct that can be described as "harassment" alters a term or condition of employment. 477 U.S. at 67 . Thus, isolated insults do not violate Title VII. Id. citing Rogers v. EEOC, 454 F.2d 234, 239 (5th Cir. 1971), cert. denied, 406 U.S. 957 (1972).

33. In one case in which co-worker harassment was deemed insufficiently pervasive and pernicious to alter the victim's conditions of employment, the harassor "routinely referred to women as 'cunt' 'pussy' and 'tits'." Rabidue v. Osceola Refining Co., 805 F.2d 611, 624 (6th Cir. 1986) (Keith, J., concurring in part and dissenting in part), cert. denied, 481 U.S. 1041 (1987).

34. See Bohen v. City of East Chicago, 799 F.2d 1180, 1184 (7th Cir. 1986) (describing relief for hostile environment violation as injunctions and reinstatement); see also supra note 9 (discussing equitable remedies under Title VII).

35. See Rabidue v. Osceola Refining Co., 805 F.2d at 620 ("unlike quid pro quo harassment which may evolve from a single incident, sexually hostile environments . . . are characterized by multiple and varied combinations and frequencies of offensive exposures").

36. See supra note 11. 
four years of providing coerced sex.$^{37}$ Because the Court only addressed the hostile environment claim, Vinson's allegations of rape and fondling as acts of sexual harassment served merely as evidence of pervasive hostility, rather than as the unwelcome advance component of quid pro quo harassment. ${ }^{38}$ The Court did not discuss whether Title VII afforded redress for Vinson's economic injuries - which may be interpreted as a signal that the Court found her discharge unrelated to sexual harassment and insufficient to support a quid pro quo claim. ${ }^{39}$

\section{Constructive Discharge}

In addition to the causes of action for sexual harassment, plaintiffs may seek back-pay relief under the general doctrine of constructive discharge for losses incurred by resigning from work involuntarily to escape illegal employment practices. ${ }^{40}$ To prove constructive discharge, plaintiffs must establish causation between a Title VII violation and resignation; ${ }^{41}$ some plaintiffs must also prove "aggravating factors" justifying a decision to leave and/or employer intent to force a victim to quit. ${ }^{42}$

In Yates $v . A v c o^{43}$ and Henson v. Dundee, ${ }^{44}$ the plaintiffs sought relief under constructive discharge. Each plaintiff proved a hostile environment violation but lost on constructive discharge grounds because she failed to meet the courts' additional burdens. ${ }^{45}$ Since the constructive discharge claims were denied, the scope of each plaintiff's relief was limited to reinstatement and an injunction. ${ }^{46}$

The court in Yates defined constructive discharge as occurring when "working conditions would have been so difficult or unpleasant that a reasonable person in the employee's shoes would have felt compelled to resign." 47 In addition to the objective reasonable person standard, the court required "inquiry into the employer's intent and the reasonably

\footnotetext{
37. Id.

38. Meritor, 477 U.S. at 63.

39. Id.

40. "A claim of constructive discharge must be based on an underlying violation of Title VII. The underlying violation may be either harassment or a discriminatory condition of employment such as unequal pay, discriminatory failure to promote or discriminatory transfer." Comment, Help Wanted, supra note 17 , at $953-54$.

41. See, e.g., Huddleston v. Roger Dean Chevrolet, 845 F.2d 900, 905 (11th Cir. 1988).

42. See, e.g., Yates v. Avco Corp., 819 F.2d 630, 637 (6th Cir. 1987) (court requiring "aggravating factor" and employer intent to cause further harm beyond victim's proof of hostile environment, which court found sufficiently pervasive to alter condition of her employment); See also Comment, Help Wanted, supra note 17, at 945 (criticizing courts' refusal to relinquish requirements of aggravating factors and employer intent as elements of constructive discharge).

43. 819 F.2d 630 (6th Cir. 1987).

44. 682 F.2d 897 (11th Cir. 1982).

45. Yates, 819 F.2d at 637 ; Henson, 682 F.2d at 905 . Critical literature has recognized the anomoly of holding plaintiffs who prove Title VII discrimination to a higher burden for constructive discharge. See Comment, Help Wanted, supra note 17, at 944.

46. See supra note 9 (discussing equitable remedies under Title VII).

47. Yates, 819 F.2d at 637.
} 
foreseeable impact of its conduct on the employee."48 The plaintiff in Yates was unable to meet these further burdens.

Constructive discharge tests, such as the one applied in Yates, ${ }^{40}$ ignore the possibility that hostile environment harassment may be different from other types of discrimination and sufficient to prove constructive discharge. ${ }^{50}$ Instead of forcing additional evidentiary burdens upon plaintiffs who have already proven a hostile enviroment violation, courts should characterize constructive discharge claims as quid pro quo harassment and broadly interpret causality between the violation and resignation. ${ }^{51}$

\section{The Erosion of Quid Pro Quo Harassment}

\section{A. Indicia of Erosion}

\section{Quid Pro Quo Behavior in Hostile Environment Analysis}

The first circuit court recognition of hostile environment harassment, in Bundy v. Jackson, ${ }^{52}$ illustrates how courts inject quid pro quo criteria in hostile environment analysis. In Bundy, the plaintiff's claim arose out of a promotion denial which was preceded by verbal sexual advances, but not threats of economic retaliation. Non-economic hostility, such as supervisors inquiring about Bundy's "sexual proclivities," also occurred. ${ }^{53}$ When Bundy complained to higher management about her supervisors' harassment, one manager stated, "any man in his right mind would want to rape you." rejection of her supervisors' advances "did not evoke in them any motive" to take economic action against her. ${ }^{.5}$ When the D. C. Circuit reviewed Bundy's claim, the court found a hostile environment violation, without ruling upon the quid pro quo claim dismissed at trial. ${ }^{56}$ The court, however, treated her promotion denial as disparate treatment sex discrimination in violation of Title VII, despite the alternate interpretation of the

48. Id.

49. Id. at 637-38.

50. For other Title VII violations, such as discriminatory firing, courts do not require victims to prove psychological harm. See Comment, Help Wanted, supra note 17, at 944. Victims of hostile environment harassment frequently experience physical illness as well as harmful psychological effects. For example, in Yates, the court described the devastating effects of a hostile workplace: "As [the plaintiff] rejected [the supervisor's] advances, he would become belligerent." About one year after the harassment began, the victim "began to suffer from severe bouts of trembling and crying which became progressively worse and eventually caused her to be hospitalized on two separate occasions," 819 F.2d at 632. See also Note, Between the Boss, supra note 16, at 447 (discussing harmful psychological effects produced by workplace hostility).

51. See infra Section IV(C) (proposing characterization of constructive discharge as quid pro quo harassment).

52. 641 F.2d 934 (D.C. Cir. 1981)

53. Id. at 939-40.

54. Id. at 940 .

55. Id.

56. Id. at 943-53. 
facts as quid pro quo harassment-that Bundy refused her supervisors' sexual advances and that they later took economic action against her. ${ }^{57}$

The court obfuscated the original sexual harassment question presented-whether Bundy's supervisors committed quid pro quo harassment-and instead found that a hostile environment claim was her sole cause of action for sexual harassment. ${ }^{58}$ The court's choice of the hostile environment claim to the exclusion of non-paradigmatic quid pro quo allegations, as well as its reliance upon disparate treatment analysis to accord back-pay relief, set a precedent which future courts followed. ${ }^{59}$

The trend of courts ignoring supervisors' threats and subsequent adverse employment decisions which are not temporally linked when facts giving rise to a hostile environment claim concurrently exist is exemplified by the Meritor litigation. For example, by calling rape "criminal conduct of the most serious nature"60 and analyzing this allegation completely within the hostile environment framework, the Court overlooked the role of rape as unwelcome sexual behavior for quid pro quo claims. ${ }^{61}$ In failing to address the relationship of rape to the subsequent economic harm Vinson suffered, the Court may have sent a signal to lower courts that rape and other physical threats are not the sort of sexual advances which precipitate quid pro quo harassment. ${ }^{62}$

In other cases, courts have viewed advances and threats as evidence of a hostile environment, to the exclusion of finding quid pro quo harassment. For example, in Hicks v. Gates Rubber Co. ${ }^{63}$ the Tenth Circuit considered comments by the plaintiff's supervisor such as "I'll get you yet," accompanied by the supervisor patting the plaintiff's buttocks, as evidence solely of hostile environment harassment; the court overlooked the fact that Hicks was later discharged. ${ }^{64}$ Like Vinson, Hicks suffered economic

\section{Id. at $939 \mathrm{n} .1$.}

58. Two authors have noted that Bundy might have been decided as a quid pro quo case. See Holtzman \& Trelz, supra note 11 , at $245 \mathrm{n}$. 37. The authors suggest that the failure to adjudicate Bundy's claim as quid pro quo harassment derived from the D.C. Circuit's desire to be the first to recognize the hostile environment claim.

59. If the court had chosen to explore the uncharted waters concerning the interplay between hostile environment and quid pro quo harassment in 1981, precedent for recognizing and accomodating the symbiotic nature of the claims may have prevented the current confusion in sexual harassment law. See infra Section III.

60. Meritor, 477 U.S. at 67.

61. This Note does not seek to make rape in and of itself actionable under Title VII; rather, rape should at least be understood as the unwelcome advance component of the quid pro quo prima facie case. See supra Section I(A).

62. In fact, the EEOC Guidelines specifically define "physical conduct of a sexual nature" as a predicate act of both quid pro quo and hostile environment. 29 C.F.R. § 1604.11(a) (1988).

63. 833 F.2d 1406 (10th Cir. 1987).

64. Id. at $1410-11$. 
detriment that was "consumed" by the persistent non-economic abuse she endured. ${ }^{65}$

\section{Importance of the Quid Pro Quo Nexus}

The trend described above, in which courts include quid pro quo behavior in the hostile environment determination, does not, standing alone, negatively affect plaintiffs nor distort sexual harassment doctrine. To the contrary, inclusion of threats and advances in analyzing the severity of hostility is proper where courts apply the quid pro quo claim to all situations where economic detriment follows this behavior. ${ }^{66}$ Certainly, threats and advances cause victims intangible psychological injury. ${ }^{67}$ The problem occurs because courts place rape, threats and advances in the hostile environment model while simultaneously neglecting to include such behavior in the quid pro quo model, as suggested by Meritor. As a result, courts experience difficulty analyzing the nexus between threats and advances and adverse decisions when supervisors also engage in hostile environment harassment.

The case of Bohen v. City of East Chicago ${ }^{88}$ illustrates this point. On Bohen's first night of work as a fire department dispatcher, she took a short nap, which was permitted, and awoke to find the senior dispatcher's hand pressed against her crotch. ${ }^{69}$ Judge Easterbrook, sitting by designation as a district court judge, found that she had endured repeated instances of degradation at work, including her captain's suggestion that a "rape in some nearby flora" would improve her disposition. ${ }^{70} \mathrm{Her}$ cool reception to sexual advances and requests to engage in "deviant sexual conduct" by her co-workers and supervisors earned her the reputation of being a lesbian."

Other testimony suggested that Bohen was an "obstreperous" employee, given to "personal grievances," wh "brought problems of her own to the work place." ${ }^{\prime 3}$ Largely on this basis, Judge Easterbrook determined

65. See also Sparks v. Pilot Freight Carriers, 830 F.2d 1554, 1556 (11th Cir. 1987) (plaintiff stated prima facie case for quid pro quo and hostile environment harassment by convincing court that her supervisor's threats "upset" her); Yates v. Avco Corp., 819 F.2d 630 (6th Cir. 1987) (court used advances to determine actionability of hostility which resulted in alleged, but unproven, constructive discharge); Henson v. Dundee, 682 F.2d 897, 904 (11th Cir. 1982) (court determining hostility based upon plaintiff's reaction to threats and advances). All of these cases involved successful plaintiffs where courts used quid pro quo behavior to find actionable hostile environment harassment.

66. Sparks, 830 F.2d at 1556, 1561-63 (11th Cir. 1987) (court used threats as evidence of both quid pro quo and hostile environment harassment).

67. See supra note 50.

68. 622 F. Supp. 1234, 1240 (N.D. Ind. 1985), aff d, 799 F.2d 1180 (7th Cir. 1986).

69. 622 F. Supp. at 1238.

70. 799 F.2d at 1183. The precise threat was "that Bohen needed someone "to drag her into the bushes for a good fuck." 622 F. Supp. at 1238.

71. 622 F. Supp. at 1238.

72. 799 F.2d at 1183; see also 622 F. Supp. at 1238-43.

73. 799 F.2d at 1183. She also was characterized as a "chronic complainer" who had "temperamental outbursts." Id. 
that Bohen's discharge after four years of abuse did not violate Title VII on ethnic discrimination grounds (Bohen was Hispanic), and stopped short of fully analyzing her quid pro quo claim. Easterbrook found that Bohen's discharge was for cause, a result of her "obstinate conduct." an unusual step, Easterbrook refused to assess whether an independent hostile environment violation occurred, since Bohen had already been fired and could not benefit from the limited equitable remedies of the hostile environment claim. ${ }^{75}$ The Seventh Circuit, affirming in part, found that "although Bohen was competent at the fundamentals of her job... she was less than a model employee when it came to getting along with fellow workers, especially her superiors."

The most problematic aspect of Bohen is both courts' failure to link the supervisor's advances with the plaintiff's ultimate discharge. Judge Easterbrook failed to explore adequately the possibility that the advances and threats of rape, combined with the discharge, evidenced quid pro quo harassment. ${ }^{77}$ By including the advances in the hostile environment claim and ignoring the potential quid pro quo nexus, Easterbrook not only deemphasized the importance of advances as a predicate for quid pro quo harassment, but also effectively vitiated the plaintiff's claim for any relief under Title VII. ${ }^{\text {s8 }}$

Similarly, the plaintiffs in Meritor, Bundy, and Hicks ${ }^{79}$ endured noneconomic lewd behavior, in addition to threats or advances and were not discharged or demoted immediately following the threats or advances. In these cases, like Bohen, the intervening presence of hostile environment harassment during the protracted period between the advances and adverse employment decisions apparently blinded the courts to the facts giving rise to quid pro quo harassment. ${ }^{80}$

74. 622 F. Supp. at 1243.

75. $622 \mathrm{~F}$. Supp. at 1244 . The court neglected to analyze the actionability of quid pro quo harassment because, after her "legal" discharge, she could not avail herself of hostile environment relief under Title VII (such as reinstatement and an injunction) because she had already been "legitimately" expelled from the workplace. The court therefore held that the remedies of Title VII are negated in the context of a legal discharge. See supra note 9 (discussion limited equitable remedies under Title VII). She could not prove she was discharged in violation of Title VII so she did not receive back pay. Id. at 1244-45. The court, however, found that Bohen stated a claim for sex discrimination under $\$ 1983$ for an equal protection violation. 799 F.2d. 1185-86.

76. 799 F.2d at 1183 . In other cases, employers similarly proffer, and courts accept, the victim's failure to get along with her harassors as a valid non-discriminatory reason for terminating her employment. E.g., Rabidue v. Osceola Refining Co., 805 F.2d 611, 615 (Gth Gir. 1986) (court rejected hostile environment claim and found plaintiff's termination justified because of "her irascible and opinionated personality and her inability to work harmoniously with co-workers.").

77. Bohen, 622 F. Supp. at 1243.

78. Id.

79. See infra Section II.

80. For example, the reviewing courts in Meritor may have focused upon the hostile environment claim because at the time of Ms. Vinson's trial, hostile environment harassment existed only in scholarly literature. See C. MacKinnon, supra note 2, at 32-47. 


\section{B. Burdens of Proof}

After a plaintiff proves her prima facie case for quid pro quo harassment, the employer assumes the burden of supporting his adverse decision with a non-discriminatory rationale; the plaintiff may then rebut an employer's non-discriminatory reason by showing the reason offered was a pretext for discrimination. ${ }^{81}$ Meritor illustrates the void in the allocation of burdens of proof for quid pro quo harassment resulting from the tendency of courts to omit, overlook, or reject non-paradigmatic quid pro quo claims in favor of hostile environment claims. By failing to analyze Vinson's claim as both hostile enviroment and quid pro quo harassment, the Court avoided resolving how a proven hostile environment violation affects a plaintiff's burden of proof for a quid pro quo claim. This omission is significant because nearly all sexual harassment plaintiffs allege both hostile environment and quid pro quo harassment. ${ }^{\mathbf{} 2}$

Moylan v. Maries County ${ }^{\mathbf{8 s}}$ provides a useful example of how courts isolate proof of hostile environment harassment from the allocation of burdens of proof for quid pro quo harassment. Moylan alleged that shortly after she commenced employment as an ambulance radio dispatcher, her supervisor, the local sheriff, began to make sexual advances (which she rebuffed) and fondled her at work. The plaintiff alleged that approximately one month thereafter, the sheriff raped her. She did not immediatedly report the incident. About ten days after the rape, the sheriff entered Moylan's office, which upset her. Two days later, the sheriff fired Moylan for falsification of her employment forms. ${ }^{84}$

The district court rejected Moylan's quid pro quo claim and did not evaluate her hostile environment claim. ${ }^{85}$ On appeal, the Eighth Circuit determined that a hostile environment claim was before the lower court

81. Noting the similarities to the disparate treatment sex discrimination, courts have adopted a variation on the McDonnell Douglas Corp. v. Green, 411 U.S. 792, 802 (1971)/Texas Dep't. of Community Affairs v. Burdine, 450 U.S. 248, 252 (1981) model for the prima facie case and burdens of proof for sexual harassment. The plaintiff must demonstrate, by a preponderance of the evidence, the five elements of the prima facie case. See supra Section $I(A)$ and accompanying notes. The burden then shifts to the defendant to show a proper, non-discriminatory reason for the decision, which may require the employer to show that the same decision would have been made absent the discrimination alleged. Comment, Help Wanted, supra note 17, at 942. If the defendant carries that burden, the plaintiff must have an opportunity to prove, by a preponderance of the evidence, that the reasons given were a pretext for discrimination. This model is described in Katz v. Dole, 709 F.2d 251, 255 (4th Cir. 1984). Under the present model, if a plaintiff can show by a preponderance of the evidence that an employer's 'non-discriminatory reason' for an adverse employment decision is pretextual, or or the alleged practice would not have occurred 'but for' discrimination, the plaintiff prevails. Some courts have allowed evidence of an independent Title VII violation to show that a given decision is pretextual in order to relieve the plaintiff's burden. E.g., Bundy v. Jackson, 641 F.2d 934, 952 (D.C. Cir. 1981).

82. For cases in which plaintiffs plead facts giving rise to both causes of action, see supra note 10.

83. 792 F.2d 746 (8th Cir. 1986).

84. Id. at 748 .

85. Id. 
and should have been addressed..$^{86}$ In upholding the district court's finding of no quid pro quo harassment, the court did not assess whether proof of a hostile environment violation could rebut the employer's nondiscriminatory reason for her discharge; Moylan therefore could not receive back-pay.

\section{Liability Standards}

In contrast to the lack of scholarly interest in the subjects previously explored, the controversy concerning employer liability standards for sexual harassment continues to spawn academic debate. ${ }^{87}$ The Supreme Court's refusal to delineate the scope of employer liability for sexual harassment in Meritor assures the perpetuation of confusion in this area ${ }^{\mathbf{8 8}}$ The discussion below demonstrates that courts presently apply strict liability for both claims of sexual harassment when plaintiffs establish the other four elements of the respective prima facie cases. ${ }^{89}$

Where the first four elements of quid pro quo harassment are proven, employers are uniformly held liable, despite divergent methodologies used by circuit courts to determine liability.$^{90}$ Courts apply a variety of interpretive tools for finding definite liability whenever plaintiffs demonstrate unwelcome sexual advances or threats and clearly linked economic retaliation. In other words, employers are always found liable for paradigmatic quid pro quo harassment, regardless of whether courts apply vicarious liability tests or derive direct employer liability from agency princples. ${ }^{91}$

Employer liability standards for supervisory hostile environment also

86. Id. at 749 .

87. See Comment, The Harms of Asking, supra note 17, at 342 n. 64 (collecting articles).

88. See Note, Sexual Harassment After Meritor, supra note 11, at 1261. Although the Court explicitly rejected strict liability, Meritor, 477 U.S. at 72, its decision compelled the perpetuation of judicial subterfuges which are nothing but strict liability in disguise. See supra notes 91-93.

89. See supra Sections II(A) and (B) (discussing elements of prima facie cases for sexual harassment).

90. See Note, Sexual Harassment After Meritor, supra note 11 at 1260-61 (explaining current liability tests used by circuit courts).

91. Some courts base this "strict liability" upon a determination that the supervisor committing quid pro quo harassment acts within the scope authority, and employers are held vicariously liable based on respondeat superior. E.g., Horn v. Duke, 755 F.2d 599, 605 (7th Cir. 1985). This method provides for liability in accordance with rule for intentional torts of servants. See RESTATEMENT (SECOND) OF AGENCY $\S 219$ (1958). Other courts find direct rather than vicarious liability based upon similar agency principles also derived from tort law. E.g., Sparks v. Pilot Freight Carriers, 830 F.2d 1554, 1561 (11th Cir. 1987).

Others base liability upon the fact that liability automatically attaches for discriminatory acts of supervisors in other Title VII contexts, which resembles strict liability and has been overuled by Meritor. E.g., Horn v. Duke, 755 F.2d 599, 605 (7th Cir. 1985); Vinson v. Taylor, 753 F.2d 141, 150-51 (D.C. Cir. 1985).

Some employ an expanded knowledge standard which permits knowledge of discriminatory actions of supervisors to be imputed to the employer. E.g., Highlander v. K.F.C. Nat'l Management Co., 805 F.2d 644, 649 (6th Cir. 1986); Craig v. Y \& Y Snacks, Inc., 721 F.2d 77, 80 (3rd Cir. 1983).

The EEOC Guidelines provide for employer liability for sexual harassment "regardless of whether the specific acts. . . were authorized or even forbidden by the employer, and regardless of whether the employer knew or should have known of their occurence." 29 C.F.R. § 1604.11(c) (1988). 
suffer from methodological differences. ${ }^{92}$ Yet liability standards for hostile environment harassment by supervisors appear to be contingent upon whether harassment alters a term or condition of employment-and this crucial determination always occurs within the context of a plaintiff experiencing economic detriment. ${ }^{93}$ The controlling factor for supervisory hostile environment claims, therefore, is not the strictness of the standard applied, but whether or not specific activities meet the threshold requirement of actionability prior to the liability determination. ${ }^{94}$ That courts

92. See Note, Sexual Harassment After Meritor, supra note 11, at 1260-61 (describing different tests). In addition to the tests for quid pro quo harassment, supra note 91, many courts apply less stringent tests, such as the actual or constructive knowledge standard. Jones v. Flagship Int'l., 793 F.2d 714, 720 (5th Cir. 1986); Moylan v. Maries County, 792 F.2d 746 (8th Cir. 1986); Henson v. Dundee, 682 F.2d 897, 910 (11th Cir. 1982). This standard requires that the employer be informed of the harassment or that the harassment be of such pervasiveness that a reasonable employer should be aware of its existence. See Jones, 793 F.2d at 720. This standard allows employers to escape liability by taking appropriate corrective action. Id.

93. All successful supervisory hostile environment plaintiffs (those stating a prima facie case) have suffered economic harm. A review of all successful supervisory harassment cases reveals three common threads uniting these plaintiffs: (1) each reviewing court included threats and/or advances in the hostility determination; (2) each experienced economic detriment: (3) each established employer liability under tests of varied stringency. See Meritor, 477 U.S. 57 (1986) (see supra note 11) (Court recognized advances and proposed common law agency liability where plaintiff was fired by her harassor); Jones v. Wesco Investments, 846 F.2d 1154, 1156 (8th Cir. 1988) (court used supervisor's advances to determine hostility and applied the actual or constructive knowledge liability standard); Huddleston v. Roger Dean Chevrolet, Inc., 845 F.2d 900, 905 (11th Gir. 1987) (court included supervisor's advances in hostility determination and found direct liability following Sparks, infra, in context of alleged but unproven constructive discharge); Hicks v. Gates Rubber Co., 833 F.2d 1406, 1410 (10th Cir. 1987) (court included threats in hostile environment calculus and used apparent authority liability where plaintiff was fired by her harassor); Sparks v. Pilot Freight Carriers, 830 F.2d 1554, 1561 (11th Cir. 1987) (court heavily weighed threats and advances when assessing level of hostility and applied direct liability of supervisors as agents of employer where plaintiff was fired by her harassor and stated prima facie quid pro quo case); Yates v. Avco Corp., 819 F.2d 630, 632 (6th Cir. 1987) (court included requests for dates and for a sexual relationship as evidence of hostility and applied agency principles based upon foreseeability of acts and whether harassment occurred within the scope of employment where plaintiff alleged constructive discharge); Moylan v. Maries County, 792 F.2d 746 (8th Cir. 1986) (see supra Section II(B); court used rape as evidence of hostility and based liability upon actual or constructive knowledge where plaintiff's harassor fired her); Henson v. Dundee, 682 F.2d 897, 909-910 (11th Cir. 1982) (court applying actual or constructive knowledge standard where plaintiff also stated a claim for quid pro quo harassment and could not prove constructive discharge).

No matter what test is applied, the result is that plaintiffs prevailing on the first four elements of the hostile environment case establish employer liability. Steele v. Offshore Shipbuilding is an exception to this rule. 867 F.2d 1311, 1317 (11th Gir. 1989). In Steele the Eleventh Circuit found an individual liable for a Title VII violation based upon hostile environment harassment without imposing employer liability. Id. This holding, however, must be viewed as erroneous, since Title VII applies only to employers and not individuals. See supra note 22. Accordingly, the court should have dismissed the plaintiff's claim for failing to state a prima facie case for sexual harassment. Id. (employer liability necessary element of prima facie case).

It is not inconsistent that plaintiffs who experience economic detriment and prove a supervisor threatened their employment do not prevail on quid pro quo grounds: courts also require a clear nexus between threats and economic detriment to establish quid pro quo harassment. See infra Section $\operatorname{II}(A)(2)$.

94. Id. Further, some courts and commentators have suggested that if harassment is pervasive enough to constitute actionable harassment, constructive knowledge may be inferred. See Katz v. Dole, 709 F.2d 251, 255 (4th Cir. 1984); Note, Sexual Harassment After Meritor, supra note 11, at 1262. This contention is fortified by the fact that in circuit cases where the plaintiff has proven that hostility altered a term or condition of employment, the employer has been held liable-even where courts use the least stringent "actual or constructive knowledge test." See supra note 93. 
integrate in hostile environment analysis behavior associated with quid pro quo harassment, such as threats and advances, and that this process always occurs against a background of economic harm, raises serious doctrinal concerns. ${ }^{95}$ This phenomenon desensitizes courts to the pernicious effects of psychological injuries, standing alone. ${ }^{96}$ The outcome of desentization is the imposition of liability only in hostile environment cases involving economic reprecussions. ${ }^{97}$ The doctrinal dispute with respect to liability simply separates actionable from non-actionable harassment. ${ }^{98}$

Facial inconsistency of liability tests among circuits reflects disagreement over the quality and quantity of activity necessary to produce actionable harassment, rather than a fundamental conflict over the extent to which employers should be held liable for hostile environment harassment. ${ }^{99}$ Liability is clearly not the main issue; a more sensible approach would be for courts to acknowledge that strict liability for all sexual harassment by supervisors has become the de facto judicial norm. ${ }^{100}$

\section{Negative Effects of Current Practices}

\section{A. Heightened Proof of Hostility}

When courts choose a hostile environment claim to the exclusion of a more subtle quid pro quo claim, both the plaintiff and future litigants suffer. ${ }^{101}$ This practice erects hurdles for victims seeking relief from hos-

95. See supra note 93; Section I(A).

96. See supra note 65 (discussing negative psychological effects of hostile environment harassment); see also infra note 101 (discussing origin and effect of this practice).

97. See supra note 93; infra note 112 (discussing effects of this practice).

98. See e.g., Highlander v. K.F.C. Nat'l Management Co., 805 F.2d 644, 649 (6th Cir. 1986) (court applying stringent respondeat superior liability test to unsuccessful hostile environment claim where plaintiff failed to prove her supervisor's actions altered her psychological well-being); Jones v. Flagship Int'l, 793 F.2d 714, 720 (5th Cir. 1986) (court applying actual or constructive knowledge standard for unsuccessful claim). Of course, the fact that the plaintiffs in Highlander and Jones, supra, failed to prove actionable hostility (element four of the prima facie case) means that their claims could not be maintained-even if courts used strict liability. See supra Section I(A). Courts, however, continue to generate dicta regarding the proper standard of liability when plaintiffs do not demonstrate actionable hostility. E.g., Highlander, 805 F.2d at 649.

99. By failing to recognize that every plaintiff proving pervasive hostility overcomes whatever liability standards courts employ, supra note 93 , commentators struggle with changes in the standards instead of improving the methods of adjudicating claims. See e.g., Note, Sexual Harassment After Meritor, supra note 11.

100. Since 'Title VII prohibits discrimination by employers, and defines "employer" to include any agent thereof, 42 U.S.C. $\$ 2000($ e)(b) (1982 \& Supp. IV 1986), courts have imposed liability for acts of supervisors. The rationale is that when an employer entrusts his supervisors to hire and fire he does so with an attendant duty not to discriminate in tangible and intangible ways. See Hunter v. Allis Chalmers Corp., 797 F.2d 1417, 1422 (7th Cir. 1977) (racial hostile environment). Although the Court in Meritor eschewed strict liability in favor of common law agency principles, 477 U.S. at 72 , the approach of Hunter also finds support in the common law. See Restatement (SECOND) of AGENCY (1958) $\$ 520$ (1958) (subjecting a 'master' or employer to liability for harm caused by his failure to perform duties imposed by him through statutes enacted for protection of employees); $\$ 17$ (allowing an employer to delegate these duties to agents). The Hunter approach accords with the imposition of strict liability for supervisory hostile environment harassment in Title VII racial, religious and ethnic discrimination cases. Between the Boss, supra note 16, at $458 \mathrm{n} .16$ (collecting cases).

101. This is so because quid pro quo criteria are used so often to establish hostile environment violations, and not applied to quid pro quo cases, that the present norm is that hostile environment 
tility absent economic detriment. Gases such as Meritor and Bohen provide the model that lower courts use to determine the severity of hostile environment harassment. These cases are characterized by extreme abuse in the context of a subsequent discharge, and have heightened implicitly the level of severity courts require to find actionable harassment. ${ }^{102}$

\section{B. Reduced Availability of Back-Pay}

Plaintiffs deprived of the quid pro quo claim cannot receive back-pay. Those prevailing on hostile environment claims must settle for injunctive relief or reinstatement. ${ }^{103}$ Most "successful" hostile environment plaintiffs end up with nothing ${ }^{104}$ because they were fired and could not prove quid pro quo harassment or quit and could not prove constructive discharge. ${ }^{105}$ Courts also reject adapting mixed claim adjudication to sexual harassment. Consequently, courts neglect to apply a proven claim of hostile environment harassment in determining the presence of quid pro quo harassment when the two claims arise together. ${ }^{106}$ Courts simply fail to understand the manner in which the claims interact. For example, in Bohen the plaintiff was fired for insubordination under conditions of severe workplace hostility. ${ }^{107}$ Bohen offered proof of hostile environment harassment, but the court sidestepped the independent hostile environment cause of action because no remedy would be available for a proven claim. If the court had analyzed Bohen's claim as quid pro quo harassment, a finding of hostile environment harassment would have been useful as evidence to rebut the employer's decision as pretext; that is, if she had been permitted to prove a hostile environment violation, the court would have

plaintiffs' cases include firing or constructive discharge-economic harm-rather than the noneconomic harm that hostile environment harassment developed to rectify. See supra note 10 and cases cited therein. At a minimum, this Note argues that the common thread of economic loss running throughout hostile environment cases raises de facto the standard of pervasive hostility required to maintain an action under Title VII.

102. See supra Section II(A).

103. See supra Section II(A)(2); see also Bohen v. City of East Chicago, 799 F.2d 1180, 1184 (7th Cir. 1986); Note, Sexual Harassment After Meritor, supra note 11, at 1262.

104. In the context of constructive discharge, both types of relief are useless because the employee has quit her job. E.g., Henson v. Dundee, 682 F.2d 897, 904 (11th Cir. 1982). Plaintiffs who are fired but do not prevail on quid pro quo claims are similarly situated. E.g., Vinson v. Taylor, 753 F.2d 141, 143 (D.C. Cir. 1985).

105. See, e.g., Bohen v. City of East Chicago, 799 F.2d 1180, 1183 (7th Cir. 1986) (plaintiff unable to prove quid pro quo discharge); Yates v. Avco Co., 819 F.2d 630 (6th Cir. 1987) (court using advances to find actionable hostility which resulted in an alleged, but unproven constructive discharge).

106. E.g., Sparks v. Pilot Freight, 830 F.2d 1554, 1557 (11th Cir. 1987) (court found both hostile environment and quid pro quo harassment but did not resolve how claims interacted).

107. Bohen v. City of East Chicago, 799 F.2d 1180, 1183 (7th Cir. 1986). 
been forced to decide whether insubordination was a proper reason for a discharge by a supervisor who participated in the violation. ${ }^{108}$

\section{Proposals For Change}

\section{A. Distinguishing Claims}

Courts must recognize that hostile environment and quid pro quo harassment are not mutually exclusive causes of action, but complementary claims for relief. ${ }^{109}$ Approaches which conflate the two claims fail to account for the fact that each claim contemplates specific remedies for specific illegal behavior by supervisors. Courts developed quid pro quo harassment to rectify economic loss suffered from sexual harassment; extending quid pro quo doctrine to all economic harm inflicted by sexual harassment builds logically upon existing precedent. ${ }^{110} \mathrm{~A}$ hostile environment claim is distinct, however, from quid pro quo harassment, but now remains contingent upon the presence of quid pro quo activities. ${ }^{111}$ The hostile environment cause of action must be re-claimed as a remedy for non-economic abuse in the workplace. ${ }^{112}$

108. See supra Section II(B) (discussing role of hostile environment violation in allocation of burdens of proof for concurrent quid pro quo claim).

109. This view opposes those which view the two claims as one along a continuum. See supra note 16 .

110. Preserving the two causes of action comports with the historical evolution of the doctrine. See Holtzman \& Trelz, supra note 11, at 446 (descibing hostile environment claim as "opening up the door to new claims" by allowing plaintiffs to prevail without suffering economic harm). The conflation approach undermines the legitimacy of the hostile environment cause of action as an independent violation of Title VII Given the current doctrinal problems in sexual harassment law, described in Section I, a complete overhaul of the system might reinforce the tendency of courts to favor hostile environment over quid pro quo harassment. One could imagine courts, under the conflation scenario, labelling all sexual harassment hostile environment and refusing to award back-pay to any plaintiff. See supra Section II.

111. See supra Section II(A)(1); see also supra note 93 and accompanying text.

112. Because all supervisory hostile environment plaintiffs experience economic detriment, see supra note 10, including those who cannot establish a prima facie case, see Jones v. Flagship Int'l., 793 F.2d 714, 718 (5th Cir. 1986), the mere presence of economic detriment cannot be controlling in courts' assessment of whether an actionable hostile environment exists. Rather, this Note observes that under current practices, economic loss is a necessary but not sufficient condition for proving hostility. This observation has two implications: (1) the presence of economic detriment in nearly all cases reaching the circuit courts, see supra note 10, may "chill" plaintiffs who do not experience economic harm from bringing suit; (2) against the prevailing background of economic harm plaintiffs bring to court, $i d$., courts' reliance upon offensive behavior associated with element two of the quid pro quo prima facie case (such as advances and threats, see supra note 93 and accompanying text), as proof of hostility, disadvantages plaintiffs whose harassors do not rely upon these quid pro quo activities to terrorize women in the workplace. Compare cases cited supra notes 93 with Rabidue v. Osceola Refining Co., 805 F.2d 611, 622 (6th Cir. 1986), cert. denied, 481 U.S. 1041 (1987) (plaintiff's coworkers behavior, which did not include unwelcome advances or threats-but did include vulgar and demeaning language as well as pornography-was not considered sufficiently hostile). Id. at 624 (Keith, J., concurring in part and dissenting in part). See supra note 33. 


\section{B. Mixed Claim Adjudication Where an Employee is Fired Demoted or Denied Promotion}

A full and faithful application of each claim's prima facie case provides a useful starting point for distinguishing between claims. ${ }^{113}$ As the first step, if any form of economic detriment is alleged, courts should treat the claim as an allegation of quid pro quo harassment. ${ }^{114}$ If threats and/or advances were followed by economic detriment, as in Meritor, the potential nexus between the threat and detriment must be explored. Courts should discard the strict requirement of a close temporal link of paradigmatic quid pro quo adjudication. ${ }^{118}$

Second, after determining the applicability or non-applicability of the quid pro quo case, hostile environment harassment must be examined independently. Where a hostile environment is alleged, courts, consistent with Meritor, must consider whether or not the hostility rose to an actionable level by affecting a "term or condition of employment."116 With respect to the hostile environment determination, courts should recognize the offensiveness of lewd language and pornography, instead of relying upon threats and advances to aseess hostility. ${ }^{112}$

Third, since a plaintiff may rebut an employer's facially correct employment decision as pretextual, the plaintiff must be permitted to use evidence that a hostile environment induced poor performance to demonstrate pretext. ${ }^{118}$ If hostile environment harassment created behavior on the part of a plaintiff which precipitated an adverse job decision, the decision would not have occurred "but for" the illegal activity. ${ }^{119}$ Clearly, a decision to terminate under these conditions should not qualify as nondiscriminatory if termination would not have occurred "but for" a Title VII violation.

Similarly, where plaintiffs have been fired, but not propositioned, and where an independent hositle environment violation has been found, courts should look for any connection between the environmental violation and the adverse decision. Courts thus should examine the claim as quid pro quo harassment. In formal terms, courts should characterize the hostile environment as the unwelcome sexual behavior (element two of the prima facie case) necessary to establish quid pro quo harassment. Determining the presence or absence of a nexus between the adverse decision

113. See supra Section I and accompanying notes.

114. E.g., Horn v. Duke, 755 F.2d 588, 601 (7th Cir. 1985).

115. See supra Section II(A)(2) (discussing problems associated with strict nexus requirement).

116. 477 U.S. at 67 (1986).

117. For examples of severely offensive behavior, see supra Section I(A).

118. See supra note 81 (discussing burdens of proof); see also Bundy v. Jackson, 641 F.2d 934, 951 (D.C.Cir. 1981) (using hostile environment claim to alleviate plaintiffs's disparate treatment sex discrimination claim). This procedure could also be applied to the quid pro quo model.

119. Bohen v. City of East Chicago, 622 F. Supp. 1234 (N.D. Ind. 1985), affd, 799 F.2d 1180, 1242 (7th Cir. 1986). 
and hostile environment harassment is analogous to the inquiry courts make in paradigmatic quid pro quo cases between the supervisor's threats and adverse economic detriment. ${ }^{120}$ This "new" version of quid pro quo harassment is in accordance with the Equal Employment Oppurtunity Commission Guidelines and fulfills the purpose of the quid pro claim as a remedy for economic detriment due to sexual harassment. ${ }^{121}$

\section{Mixed Claim Ajudication Involving Resignation}

This Note argues that when women quit work because of a hostile environment violation, quid pro quo harassment occurs. Constructive discharge entails economic detriment, but differs from the classic quid pro quo model in two ways: (1) the unwelcome sexual harassment "resulting in tangible detriment" consists of a proven hostile environment claim rather than unwelcome sexual demands;, ${ }^{122}$ and (2) a supervisor's employment decision does not produce the economic loss suffered, but his actions do. ${ }^{123}$ In restricting the scope of unwelcome sexual harassment required for quid pro quo claims to advances or demands, courts allow sexual harassment law to abandon these plaintiffs.

Courts exclude from quid pro quo doctrine plaintiffs who quit work, prove hostile environment harassment, but cannot prove constructive discharge. As a result, back-pay relief becomes unavailable. ${ }^{124}$ The quid pro quo prima facie case provides a useful framework for anaysis of these sexual harassment constructive discharge claims. ${ }^{125}$ Analyzing the existence of nexus between the hostile environment violation and the decision

120. See Hicks v. Gates Rubber Co., 833 F.2d 1406, 1413 (10th Cir. 1988) (discussing necessity of establishing nexus between advances or threats and adverse job decisions to prevail on claim of quid pro quo harassment). The nexus inquiry for this type of claim must also be broadened, as explained supra note 115 and accompanying text.

121. See 29 C.F.R. $\$ 1604.11$ (1)(2)(1988).

122. E.g., Jones v. Flagship Int'l, 793 F.2d 714, 722 (5th Gir. 1986) (discussing as necessary adverse action by employer to prove quid pro quo harassment).

123. Successful hostile environment plaintiff, moreover, may not recover damages for emotional distress. Yates v. Avco Corp. 819 F.2d at 630, 638 (6th Cir. 1987).

124. Allowing proof of hostile environment harassment to establish constructive discharge and labelling the claim quid pro quo harassment allows the entire claim to be resolved within sexual harassment doctrine, as opposed to the uncertainty posed by the various tests courts use to analyze constructive discharge. Compare Yates, 819 F.2d at 637, with Huddleston v. Roger Dean Chevrolet Inc., 845 F.2d 900, 904 (11th Cir. 1988) (two different constructive discharge tests).

125. One commentator suggests, "A hostile work environment case that results in constructive discharge is very much like a tangible benefit case. . the difference between the two cases is that in tangible benefit cases, the supervisor has exercised his right to fire." Note, Between the Boss, supra note 16, at 467 . This Note, however, extends the analogy further: by perpetrating hostile environment harassment, the supervisor directly makes a type of sexual demand which victims should not be made to endure. 
to quit parallels the nexus inquiry previously proposed for non-paradigmatic quid pro quo cases. ${ }^{126}$

\section{Conclusion}

The observations posited above do not purport to be "outcome determinative"; thus, each and every case critiqued for failures in the adjudicatory process could easily have been decided the same way under the theory proposed. The focus of this Note, however, is to underline the fact that plaintiffs do not receive the proper opportunity to plead and prove quid pro quo allegations as a separate claim, and that this systemic failure in the courts has lead to both a restriction of quid pro quo back-pay relief and a limitation of actionable hostile environment harassment.

Distinguishing the claims by economic detriment comports well with the spirit of Title VII, since the statutory language "terms and conditions of employment" has been read broadly to include a variety of discriminatory activities. ${ }^{127}$ This Note's proposal, to include all economic detriment within the definition of quid pro quo harassment is reasonable and consistent with Title VII precedent in other areas. ${ }^{128}$ In describing Title VII, one court explained:

Congress chose neither to enumerate specific discriminatory practices, nor elucidate in extenso the pattern of such nefarious activities. Rather, it pursued the path of wisdom by being unconstrictive, knowing that constant change is the order of the day and that the seemingly reasonable practices of the present can easily become the injustices of the morrow. ${ }^{129}$

Because quid pro quo doctrine is judge-made law, and developed to compensate women economically disadvantaged by sex discrimination, the doctrine should naturally evolve to accomodate all situations where women suffer deleterious tangible effects as a result of sexual harassment. Courts, further, should re-evaluate standards of the offensiveness and pervasiveness ${ }^{130}$ of workplace behavior which is not characteristically associated with economic detriment. ${ }^{131}$ Finally, the standards for assessing

126. See supra Section II(A)(2) (discussing necessity of broadly interpreting nexus between threats or advances and adverse decisions in quid pro quo cases).

127. See Los Angeles Dept. of Water \& Power v. Manhart, 435 U.S. 702, 711 (1977) (abolishing insurance plan which disadvantaged women based upon stereotype that women live longer than men).

128. See Albermarle Paper Co. v. Moody, 422 U.S. 405, 418-423 (1975) (purpose of Title VII is to "make whole" victims of illegal discrimination).

129. Rogers v. EEOC, 454 F.2d 234, 239 (5th Cir. 1971), cert. denied, 406 U.S. 957 (1972).

130. See Note, Abusive Work Environment, supra note 11, at 1502 (adopting reasonable woman standard to judge offensiveness of behavior).

131. For example, courts do not view photographs and posters of nude and scantily clad women as offensive conduct associated with economic harm in the workplace. See Rabidue v. Osceola Refining Co., 805 F.2d 611, 619 (6th Cir. 1986). Yet, even in Rabidue, a co-worker case, the plaintiff was fired partly because of her inability to get along with her co-workers-men who regularly displayed pornography, and used lewd language. See supra note 33. 
women's psychological harm due to harassment must begin to reflect women's sensitivity to behavior once condoned as acceptable. ${ }^{132}$

132. See, e.g., Rabidue v. Osceola Refining Co., 805 F.2d 611, 622 (6th Cir. 1986), where the court stated: "The sexually oriented posters had a minimum effect on the plaintiff's work environment when considered in the context of a society. . .that. . exploits open displays of erotica." 